\author{
Asian Journal of \\ Medical and Biological Research \\ ISSN 2411-4472 (Print) 2412-5571 (Online) \\ www.ebupress.com/journal/ajmbr
}

\title{
Article \\ Changes in hematological parameters and gill morphology in common carp exposed to sub-lethal concentrations of Malathion
}

\author{
Sadia Sharmin ${ }^{1}$, Md. Abdus Salam ${ }^{1}$, Farhana Haque ${ }^{2}$, Md. Sadiqul Islam ${ }^{2}$ and Md. Shahjahan ${ }^{1, *}$ \\ ${ }^{1}$ Department of Fisheries Management, Bangladesh Agricultural University, Mymensingh-2202, Bangladesh \\ ${ }^{2}$ Department of Fisheries Biology and Genetics, Bangladesh Agricultural University, Mymensingh-2202, \\ Bangladesh
}

${ }^{*}$ Corresponding author: Dr. Md. Shahjahan, Department of Fisheries Management, Bangladesh Agricultural University, Mymensingh-2202, Bangladesh. E-mail: mdshahjahan@bau.edu.bd

Received: 18 July 2016/Accepted: 19 September 2016/ Published: 29 September 2016

\begin{abstract}
Malathion is an organophosphorous insecticide widely used in the agricultural field in Bangladesh and reach in the aquatic environment through rain wash. In the present study, we examined the effects of Malathion on hematological parameters and gills morphology in common carp exposed to two sub-lethal concentrations $(1.5$ and $3.0 \mathrm{mg} / \mathrm{L})$ for a period of $192 \mathrm{~h}(8$ days $)$. For hematological parameters fish were sacrificed at 24, 48, 72, and 96h after start of exposure. Gills were collected at $192 \mathrm{~h}$ after start of exposure. The blood glucose level was significantly elevated with increasing the concentration of Malathion. Red blood cells (RBCs), hemoglobin $(\mathrm{Hb})$ and hematocrit (Hct) values were significantly decreased after the exposure of Malathion. Significant increments were observed in case of the mean corpuscular volume (MCV) and mean corpuscular hemoglobin concentration (MCHC), while no distinct changes were noted for mean corpuscular hemoglobin (MCH). Interestingly, white blood cells (WBCs) count was significantly increased with toxicity of Malathion. Several morphological changes, such as telangiectasia, blood lamellar congestion, hypertrophy of filaments, lamellar fusion were observed in the gills of fish exposed to Malathion. The present study revealed that the insecticide had adverse effects on various blood parameters and gills morphology in common carp. Thus, the use of insecticide in the agriculture field may be a threat to fauna and flora of the aquatic environment.
\end{abstract}

Keywords: fish; environment; pesticide; toxicology; histopathology

\section{Introduction}

In the last few decades, indiscriminate use of insecticides has raised the risk of contamination of terrestrial environment as well as aquatic habitat. Though they have been used for the safety of humans, their harmful effects are alarming on other non-target animals like fish. Contamination of water by insecticides, either directly or indirectly can lead to fish kills and reduced productivity of waterbodies (Rahman et al., 2012; Siddika et al., 2012; Talukdar et al., 2012; Nupur et al., 2013). In Bangladesh, more than 300 types of pesticides and insecticides are used for crop protection in agriculture (Uddin et al., 2016). Malathion (O, O-dimethyl dithiophosphate of diethyl mercaptosuccinate) is an insecticide in the chemical family known as organophosphates. Products containing Malathion are used outdoors to control a wide variety of insects in agricultural settings and around people's homes. It has been used in public health mosquito control and fruit fly eradication programs. Malathion may also be found in some special shampoos for treating lice. Malathion is toxic via skin contact, ingestion, and inhalation exposure (Tomlin, 2006). The organophosphate compounds altered metabolic activities to death of fishes (Anam and Mitra, 1995). It is important to examine the toxic effects of pesticides on fish as the fish is an important part of the food chain of human. 
Similar to mammalian species fish appear to possess the same biochemical pathways to deal with the toxic effects of endogenous and exogenous agents (Lackner, 1998). Hematological parameters like Hb, Hct, and blood cell counts can be used to find physiological responses of contaminated environment (Dethloff et al., 2001; Salam et al., 2015; Sharmin et al., 2015; Sharker et al., 2015; Shahjahan et al., 2016). Therefore, the blood parameters are often measured when a clinical diagnosis of fish physiology is applied to determine the sub-lethal effects of pollutants (Venkataramana et al., 2006). The effects of different pollutants on the hematological parameters have been documented in several fish species (Abalaka et al., 2011 and Al-Kahem Al-Balawi et al., 2011). However, the reports on the effects of sub-lethal dosages of Malathion in common carp, Cyprinus carpio are still scanty. Moreover, so far there is no study yet conducted in Bangladesh which warrants the present study.

The common carp is an economically important freshwater fish, native to China and has been introduced all over the world to form a significant part of freshwater fishery. It is a highly palatable and preferred for culture due to its high growth rate and prolific breeding in confined water. In the present study, an effort was made to examine the toxicity of Malathion to this fish species. The changes in hematological parameters (glucose, $\mathrm{Hb}$, cell counts and Hct) were monitored after sub-lethal exposure of this insecticide. In addition, effects of Malathion on histoarchitecture of gills were examined after sub-lethal exposure of this insecticide.

\section{Materials and Methods}

\subsection{Animals and insecticide}

Healthy and active specimens of common carp (Cyprinus carpio) were collected from local fish farm. The length and weight of fishes ranged from 14 to $16 \mathrm{~cm}$ and 50 to $70 \mathrm{~g}$, respectively. The fishes were maintained in aquaria at $25 \pm 0.5^{\circ} \mathrm{C}$ under a controlled natural photo-regimen $(14 / 10 \mathrm{~h}$, light/dark) for a period of 21 days before the experiments. The fish were fed twice a day. The experimental procedures followed the guidance approved by the Animal Care and Use Committees of Bangladesh Agricultural University, Mymensingh, Bangladesh. To conduct the present study, the Malathion with 57\% active ingredient was collected from local retail pesticide shop.

\subsection{Experimental design and sample collection}

To conduct the experiment nine aquaria $(75 \mathrm{~cm} \times 45 \mathrm{~cm} \times 45 \mathrm{~cm})$ were first cleaned and washed thoroughly by tap water. Then the aquaria were filled with $100 \mathrm{~L}$ of tap water. The experiment was conducted with three treatments, each with three replications. Two sub-lethal concentrations $(1.5$ and $3.0 \mathrm{mg} / \mathrm{L})$ were selected considering the $96 \mathrm{~h} \mathrm{LC50} \mathrm{(15.24} \mathrm{mg/L)} \mathrm{value} \mathrm{(Sharmin} \mathrm{et} \mathrm{al.,} \mathrm{2015).} \mathrm{A} \mathrm{control} \mathrm{set} \mathrm{was} \mathrm{also} \mathrm{run} \mathrm{for} \mathrm{the} \mathrm{same}$ time and with the same number of fish but without Malathion. Ten fish were transferred in each aquarium. For hematological parameters fish were sacrificed at 24, 48, 72, and $96 \mathrm{~h}$ after start. Gills were collected at $192 \mathrm{~h}$ after start and preserved in $10 \%$ formalin until use for sectioning.

\subsection{Blood sampling and measurement of hematological parameters}

After each exposure periods of Malathion, blood was collected from the caudal peduncle into citrated tuberculin syringes. Blood glucose $(\mathrm{mg} / \mathrm{dL})$ and hemoglobin $(\mathrm{Hb} ; \mathrm{g} / \mathrm{dL})$ were measured using glucose and hemoglobin strips in a digital EasyMate ${ }^{\circledR} \mathrm{GHb}$, blood glucose/haemoglobin dual-function monitoring system. Hematocrit (Hct; \%) values were determined by using a micro-hematocrit centrifuge. The red blood cell $\left(\mathrm{RBC}, \mathrm{x} 10^{6} / \mathrm{mm}^{3}\right)$ and white blood cell (WBC, $\times 10^{4} / \mathrm{mm} 3$ ) count was made using Neubauer hemocytometer. The mean corpuscular volume $\left(\mathrm{MCV}, \mu \mathrm{m}^{3}\right)$, the mean corpuscular hemoglobin $(\mathrm{MCH}, \mathrm{pg})$ and the mean corpuscular hemoglobin concentration (MCHC, \%) were calculated using the following formulas (Jain, 1993) :

$\mathrm{MCV}=(\%$ of $\mathrm{Hct} / \mathrm{RBC}$ in millions $) \times 10 \mu \mathrm{m}^{3}$

$\mathrm{MCH}=(\mathrm{Hb}$ in $\mathrm{g} / \mathrm{RBC}$ in millions $) \times 10 \mathrm{pg}$

$\mathrm{MCHC}=(\mathrm{Hb}$ in $\mathrm{g} /(\%$ of $\mathrm{Hct}) \times 100 \mathrm{~g}$ per $100 \mathrm{~mL}$

\subsection{Histology of gills}

The fixed gills were passed through graded alcohol series to dehydrate them. The dehydrated gill samples were embedded into paraffin. The embedded gill samples were sectioned at 5-10 $\mu \mathrm{m}$ thickness using microtome machine (KD- 3358, Kedee, USA). The gill sections were then stained with hematoxylene-eosin stain. Finally the gill sections were observed under microscope and taken photograph at $10 \times$ magnifications. 
2.5. Statistical analysis

Values are expressed as means \pm standard deviation (SD). Data were analyzed by one-way analysis of variance (ANOVA) followed by Tukey's post hoc test to assess statistically significant differences among different treatments. Statistical significance was set at $P<0.05$. Statistical analyses were performed using PASW Statistics 18.0 software (IBM SPSS Statistics, IBM, Chicago, USA).

\section{Results}

\subsection{Effects of Malathion on blood glucose}

We examined the blood glucose levels after exposure of fish to Malathion. The blood glucose levels were significantly $(\mathrm{P}<0.05)$ increased with increasing the concentrations $(1.5$ and $3.0 \mathrm{mg} / \mathrm{L})$ of Malathion compared to control $(0 \mathrm{mg} / \mathrm{L})$ at $24,48,72$, and $96 \mathrm{~h}$ of exposure periods (Figure 1). The glucose levels in control fishes were ranged from 104.67 to $115.00 \mathrm{mg} / \mathrm{dL}$.

\subsection{Effects of Malathion on hemoglobin (Hb)}

$\mathrm{The} \mathrm{Hb}$ of blood was measured after exposure of fish to Malathion. The $\mathrm{Hb}$ values in control fishes were ranged from 13.27 to $14.27 \mathrm{~g} / \mathrm{dL}$ (Figure 2). The values of $\mathrm{Hb}(\mathrm{g} / \mathrm{dL})$ was significantly $(\mathrm{P}<0.05)$ decreased due to the toxicity of Malathion at 24, 48, 72 and $96 \mathrm{~h}$ of exposure periods in both concentrations $(1.5$ and $3.0 \mathrm{mg} / \mathrm{L})$ compared to control $(0 \mathrm{mg} / \mathrm{L})$.

\subsection{Effects of Malathion on red blood cells (RBCs)}

Similar to $\mathrm{Hb}$, RBCs $\left(\times 10^{6} / \mathrm{mm}^{3}\right)$ values were significantly $(\mathrm{P}<0.05)$ decreased during the toxicity of Malathion at $24,48,72$ and $96 \mathrm{~h}$ of exposure periods in both concentrations $(1.5$ and $3.0 \mathrm{mg} / \mathrm{L})$ compared to control group $(0 \mathrm{mg} / \mathrm{L})$. The RBCs $\left(\times 10^{6} / \mathrm{mm}^{3}\right)$ values varied from 5.583 to $7.700\left(\times 10^{6}\right)$ cells $/ \mathrm{mm}^{3}$ in the fishes of all groups (Figure 3).

\subsection{Effects of Malathion on hematocrit/pet cell volume (Hct/PCV)}

The Hct (\%) values in control fishes were ranged from $36.61 \%$ to $37.53 \%$ (Figure 4). Similar to $\mathrm{Hb}$ and RBCs, Hct/PCV $(\%)$ was significantly $(\mathrm{P}<0.05)$ decreased with increasing the toxicity of Malathion at 24, 48, 72 and $96 \mathrm{~h}$ of exposure periods in both concentrations $(1.5$ and $3.0 \mathrm{mg} / \mathrm{L})$ compared to control $(0 \mathrm{mg} / \mathrm{L})$.

\subsection{Effects of Malathion on MCV, MCH and MCHC}

We calculated the mean corpuscular volume (MCV), the mean corpuscular hemoglobin $(\mathrm{MCH})$ and the mean corpuscular hemoglobin concentration $(\mathrm{MCHC})$. The MCV showed significant $(\mathrm{P}<0.05)$ decreasing tendency with the increasing of toxicity of Malathion at 24, 48, 72, and 96h, while MCH showed no noticeable changes (Table 1). On the other hand, significant $(\mathrm{P}<0.05)$ increments were observed in case of MCHC.

\subsection{Effects of Malathion on white blood cells (WBCs)}

The values of WBCs $\left(\times 10^{4} / \mathrm{mm}^{3}\right)$ are presented in Figure 5. There was a significantly $(\mathrm{P}<0.05)$ increase of WBCs in experimental groups $(1.5$ and $3.0 \mathrm{mg} / \mathrm{L})$ compared to control group $(0 \mathrm{mg} / \mathrm{L})$ at $24,48,72$, and $96 \mathrm{~h}$ of exposure periods.

\subsection{Effects of Malathion on gills morphology}

In the present study, morphological changes in gills exposed to Malathion were examined by histological analysis (Figure 6). The gills of fish exposed to low dose $(1.5 \mathrm{mg} / \mathrm{L})$ showed curling and clubbing of secondary lamellae called talangiectasis (T) and barrier for blood movement called blood lamellar congestion (C), while talangiectasis (T), blood lamellar congestion (C), hypertrophy of filaments $(\mathrm{H})$, edema with lifting of lamellar epithelium and hyperplasia of lamellar epithelium called lamellar fusion (LF) were observed in the gills of fish exposed to high concentration $(3.0 \mathrm{mg} / \mathrm{L})$. 
Table 1. Changes in MCV, MCH and MCHC of common carp exposed to different concentrations of Malathion.

\begin{tabular}{|c|c|c|c|c|c|}
\hline \multirow{2}{*}{ Parameters } & \multirow{2}{*}{ Concentrations } & \multicolumn{4}{|c|}{ Exposure time (hours) } \\
\hline & & 24 & 48 & 72 & 96 \\
\hline \multirow{3}{*}{$\operatorname{MCV}\left(\mu \mathrm{m}^{3}\right)$} & Control & $47.81 \pm 1.50$ & $52.42 \pm 0.75$ & $50.32 \pm 0.58$ & $50.48 \pm 1.63$ \\
\hline & $1.5 \mathrm{mg} / \mathrm{L}$ & $32.92 \pm 1.37 *$ & $44.44 \pm 2.00^{*}$ & $51.86 \pm 1.58$ & $49.37 \pm 1.90$ \\
\hline & $3.0 \mathrm{mg} / \mathrm{L}$ & $35.65 \pm 1.32 *$ & $41.00 \pm 1.92 *$ & $42.19 \pm 1.42 *$ & $44.46 \pm 2.00 *$ \\
\hline \multirow{3}{*}{$\mathrm{MCH}(\mathrm{pg})$} & Control & $17.40 \pm 1.92$ & $19.93 \pm 0.33$ & $18.50 \pm 1.07$ & $17.51 \pm 1.39$ \\
\hline & $1.5 \mathrm{mg} / \mathrm{L}$ & $17.59 \pm 0.46$ & $19.06 \pm 0.26$ & $19.61 \pm 0.88$ & $19.90 \pm 0.63$ \\
\hline & $3.0 \mathrm{mg} / \mathrm{L}$ & $16.73 \pm 0.64$ & $18.10 \pm 0.58$ & $19.34 \pm 0.30$ & $18.05 \pm 0.58$ \\
\hline \multirow{3}{*}{$\mathrm{MCHC}(\%)$} & Control & $36.40 \pm 4.00$ & $38.01 \pm 6.14$ & $36.77 \pm 1.66$ & $34.69 \pm 3.99$ \\
\hline & $1.5 \mathrm{mg} / \mathrm{L}$ & $53.44 \pm 1.04 *$ & $42.88 \pm 2.76$ & $37.82 \pm 5.23$ & $40.31 \pm 1.51 *$ \\
\hline & $3.0 \mathrm{mg} / \mathrm{L}$ & $46.94 \pm 2.24 *$ & $44.13 \pm 4.18^{*}$ & $45.85 \pm 0.25^{*}$ & $40.59 \pm 0.89 *$ \\
\hline
\end{tabular}

Asterisk (*) indicate the statistically significantly different $(\mathrm{P}<0.05, \mathrm{n}=6)$.

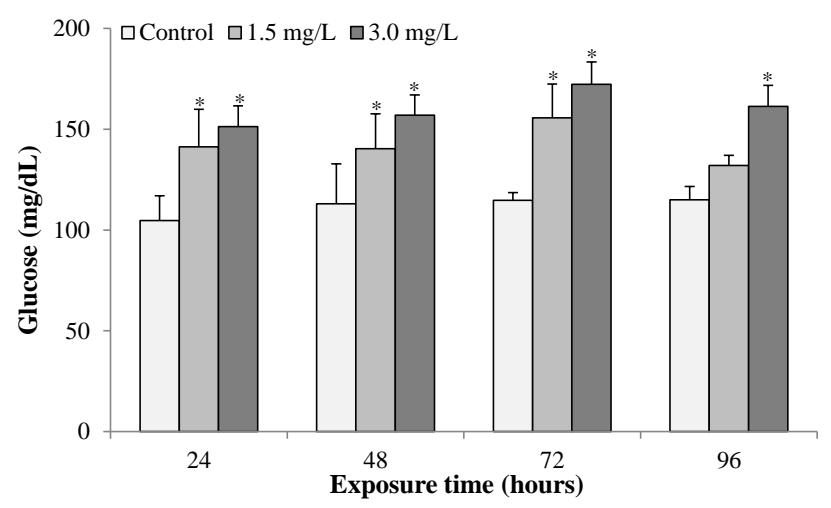

Figure 1. Changes in blood glucose levels (Means \pm SEM) of common carp exposed to sub-lethal dosage of Malathion at different time intervals. The blood glucose levels of fish exposed to $1.5 \mathrm{mg} / \mathrm{L}$ and 3.0 $\mathrm{mg} / \mathrm{L}$ Malathion were compared to the fish of control group $(0 \mathrm{mg} / \mathrm{L})$. Asterisk (*) indicate the statistically significantly different $(P<0.05, n=6)$.

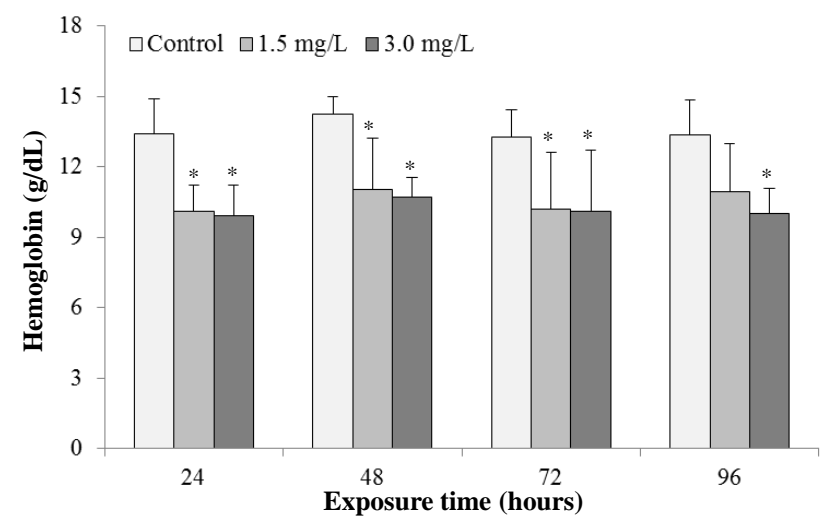

Figure 2. Changes in hemoglobin (Means \pm SEM) of common carp exposed to sub-lethal dosage of Malathion at different time intervals. The haemoglobin of fish exposed to $1.5 \mathrm{mg} / \mathrm{L}$ and $3.0 \mathrm{mg} / \mathrm{L}$ Malathion were compared to the fish of control group $(0 \mathrm{mg} / \mathrm{L})$. Asterisk $(*)$ indicate the statistically significantly different $(P<0.05, n=6)$. 


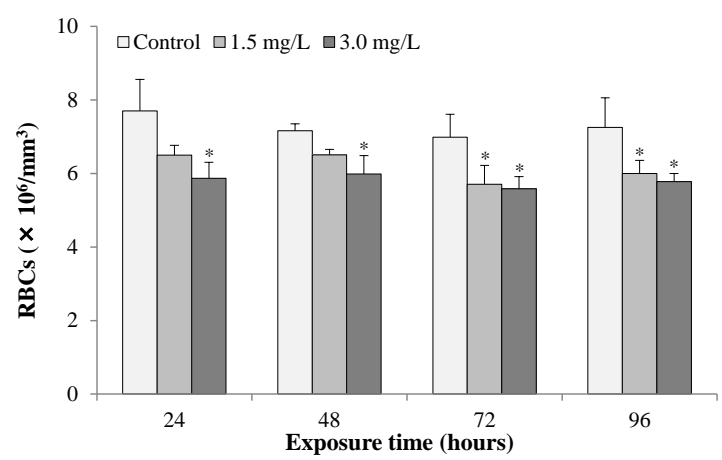

Figure 3. Changes in RBCs (Means \pm SEM) of common carp exposed to sub-lethal dosage of Malathion at different time intervals. The RBCs of fish exposed to $1.5 \mathrm{mg} / \mathrm{L}$ and $3.0 \mathrm{mg} / \mathrm{L}$ Malathion were compared to the fish of control group $(0 \mathrm{mg} / \mathrm{L})$. Asterisk $\left(^{*}\right)$ indicate the statistically significantly different $(P<0.05$, n=6).

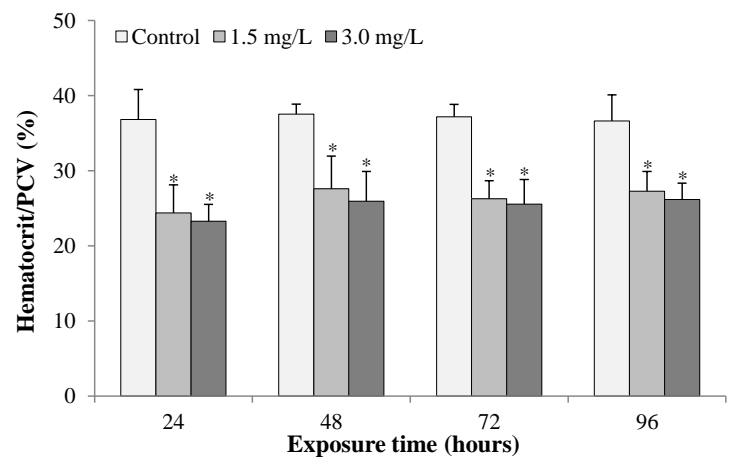

Figure 4. Changes in hematocrit/PCV (Means \pm SEM) of common carp exposed to sub-lethal dosage of Malathion at different time intervals. The haematocrit/PCV of fish exposed to $1.5 \mathrm{mg} / \mathrm{L}$ and $3.0 \mathrm{mg} / \mathrm{L}$ Malathion were compared to the fish of control group $(0 \mathrm{mg} / \mathrm{L})$. Asterisk (*) indicate the statistically significantly different $(P<0.05, n=6)$.

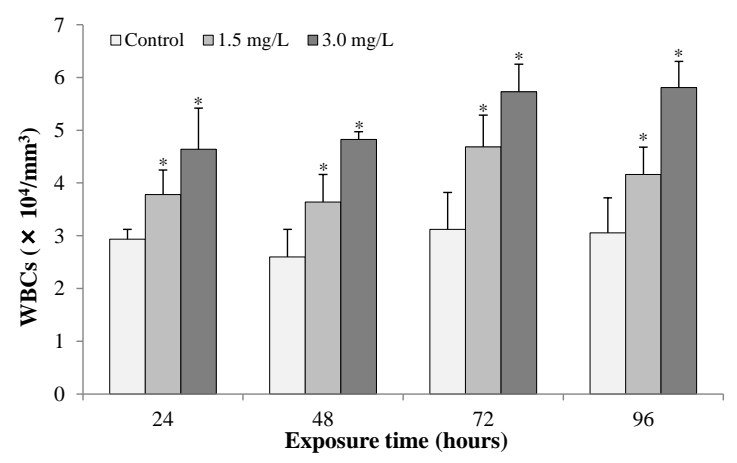

Figure 5. Changes in WBCs (Means \pm SEM) of common carp exposed to sub-lethal dosage of Malathion at different time intervals. The WBC of fish exposed to $1.5 \mathrm{mg} / \mathrm{L}$ and $3.0 \mathrm{mg} / \mathrm{L}$ Malathion were compared to the fish of control group $(0 \mathrm{mg} / \mathrm{L})$. Asterisk $(*)$ indicate the statistically significantly different $(\mathbf{P}<0.05$, $\mathrm{n}=6)$. 

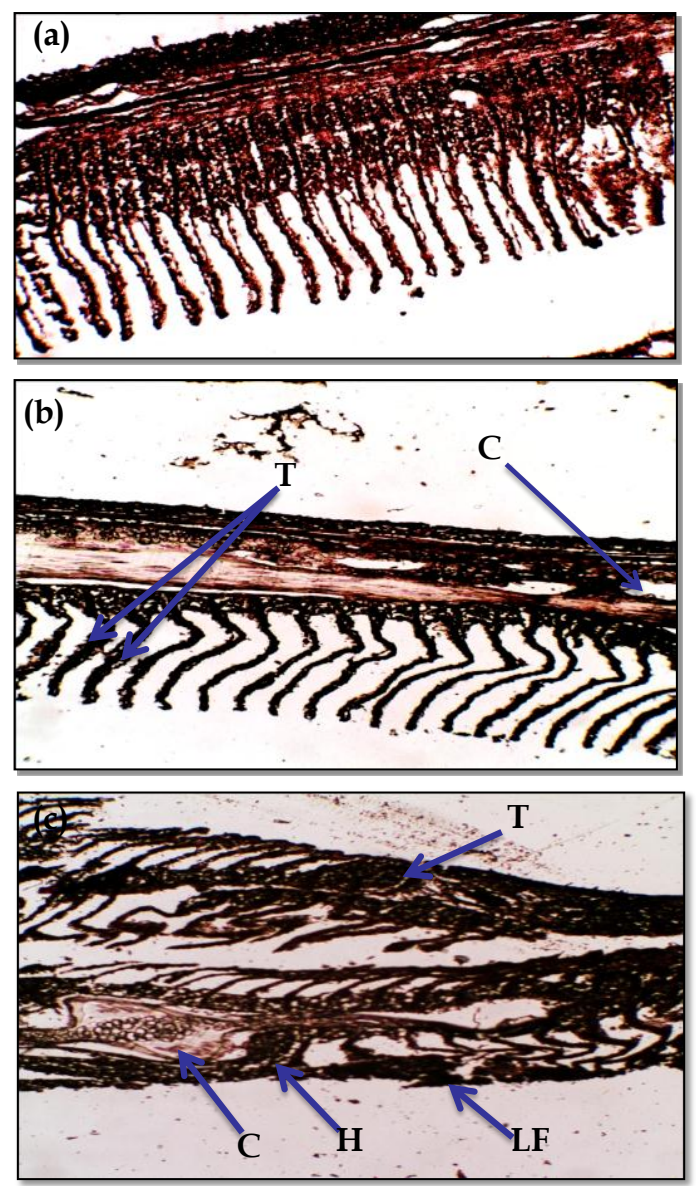

Figure 6. Morphological changes in gills exposed to Malathion; (a) Control $(0 \mathrm{mg} / \mathrm{L})$, (b) $1.5 \mathrm{mg} / \mathrm{L}$ and 3.0 $\mathrm{mg} / \mathrm{L}$. Arrowheads are indicating Talangiectasis (T), Blood Lamellar congestion (C), Hypertrophy of filaments (H), Lamellar fusion (LF).

\section{Discussion}

To understand the toxic effects of an organophosphorous insecticide Malathion on fish, we examined the effects of Malathion on hematological parameters and gill morphology of common carp. Differential changes were observed in hematological parameters and gills morphology indicating the toxicological impacts of Malathion on fish body.

The blood glucose level is the amount of glucose (sugar) present in the blood of an animal which is the primary source of energy. In the present study, increased glucose levels in the fish exposed to Malathion might be due to the mobilization of glycogen into glucose to meet the increased demand for energy. Glucocorticoids and catecholamine hormones are known to produce hyperglycemia in animals and stress stimuli elicit rapid secretion of these hormones from adrenal tissue of the fish (Pickering, 1981). Such increase may be due to enhanced gluconeogenesis response of stressed fish in their attempt to satisfy their new energy demands (Winkaler et al., 2007). The hyperglycemic condition in the present study may also be attributed to increased secretion of these hormones which causes glycolysis in the fish exposed to Malathion (Abalaka et al., 2011; Alkahem-Al-Balawi et al., 2011). The pesticide may change the functions of vital organs like liver and kidney, disrupting the homeostatic condition of the body. Similar observations have been reported in the carp, Cyprinus carpio, after the exposure of dietary copper and support to the present study (Al-Akel et al., 2010).

Significant decreases in various blood parameters ( $\mathrm{Hb}, \mathrm{RBC}$ and $\mathrm{Hct}$ ) might be because of failing of hematopoietic system in common carp exposed to Malathion. Similar to the present results, a decrease in the number of $\mathrm{RBC}, \mathrm{Hb}$ and $\mathrm{Hct}$ values were reported in common carp exposed to diazinon (Banaee et al., 2011) and in Clarius gariepinus exposed to lead nitrate (Adeyemo, 2007). Generally, toxicants exposure exerts an adverse effect on the hematopoietic organs which in turn alters blood parameters. Decline in RBCs, $\mathrm{Hb}$ and $\mathrm{Hct}$ values apparently reproduced erythrocyte hemolysis, damage of gill morphology and function in Korean rockfish (Sebastes schlegeli) exposed to cypermethrin (Jee et al., 2005). The blood cell indices like MCV, MCH and MCHC seem to be changes in the present study that can cause reversible changes in the homeostatic system 
of fish. Fluctuations in these indices correspond with values of RBCs, $\mathrm{Hb}$ and Hct. The values of blood cell indices were enhanced in common carp and other freshwater fish after the exposure of acute toxic level of pesticides (Rao, 2010; Hossain et al., 2015; Salam et al., 2015).

In the present study, WBC significantly increased with increasing the toxicity of Malathion at 24, 48, 72 and 96h of exposure periods in both concentrations compared to control (Figure 8). Increased WBC count established leucocytosis, which is considered to be of an adaptive value for the tissue under chemical stress. This also helps in the removal of cellular debris of necrosed tissue at a faster rate (Marti et al., 1996). In the presence of foreign substances or under pathological conditions leucocytosis in fish may be the consequence of direct stimulation of immunological defense (Marti et al., 1996). The increase in WBC count can be correlated with an increase in antibody production which helps in survival and recovery of the fish exposed to Malathion (Joshi et al., 2002).

In fish, the gills participate in many important functions, such as respiration, osmoregulation and excretion, remain in close contact with external environment and particularly sensitive to changes in the quality of the water are considered the primary target on contaminants (Camargo and Martinez, 2007; Fernandes and Mazon, 2003). Toxic substances can injure gills, thus reducing the oxygen consumption and disrupting the osmoregulatory function of aquatic organisms (Saravana et al., 2000). In the present study, exposure of common carp to Malathion resulted in structural alterations of the gill including talangiectasis (curling and clubbing of secondary lamellae), blood lamellar congestion (barrier for blood movement), hypertrophy of filaments, lamellar fusion (edema with lifting of lamellar epithelium and hyperplasia of lamellar epithelium). These pathological changes may be a reaction to toxicants intake or an adaptive response to prevent the entry of the pollutants thorough the gill surface and probably due to increased capillary permeability (Olurin et al., 2006). The present results are in agreement with those observed in other fish species under the influence of different pollutants (Olurin et al., 2006; Parikh et al., 2010; Ahmed et al., 2015).

\section{Conclusions}

The effects of Malathion on hematological parameters and gills morphology were examined in common carp. Malathion enhanced the blood glucose level suggests that glycogen might be breakdown to glucose due to toxicant of Malathion. On the other hand, reduction of $\mathrm{Hb}$, RBCs and Hct might be because of failing of hematopoietic system. Increased WBCs count established leucocytosis, which is considered to be of an adaptive value for the tissue under chemical stress. Several morphological changes in gills were observed which indicates a reaction to toxicants intake or an adaptive response to prevent the entry of the pollutants thorough the gill surface and probably due to increased capillary permeability. Taken all together, the present study revealed that the Malathion has adverse effects on various blood parameters and gills morphology in common carp.

\section{Conflict of interest}

None to declare.

\section{Acknowledgements}

This work was supported by a grant of Impact of Aquaculture Drugs and Chemicals on Aquatic Ecology and Productivity Project (IADCAEPP) provided by Bangladesh Fisheries Research Institute (BFRI), Mymensingh2201, Bangladesh.

\section{References}

Abalaka SE, KAN Esievo and SVO Shoyinka, 2011. Evaluation of biochemical changes in Clarias gariepinus adults exposed to aqueous and ethanolic extracts of Parkia biglobosa pods. Afr. J. Biotechnol., 10: 234-240.

Adeyemo OK, 2007. Haematological profile of Clarias gariepinus (Burchell, 1822) exposed to lead. Turkish J. Fish. Aquat. Sci., 7: 163-169.

Ahmed SI, MK Ahmmed, SK Ghosh, MM Islam and M Shahjahan, 2015. Histo-architectural changes of intestinal morphology in zebrafish (Danio rerio) exposed to sumithion. Res. Agric. Livest. Fish., 2: 499-506.

Al-Akel A, HF Alkahem-Al-Balawi, F Al-Misned, S Mahboob, Z Ahmad and EM Suliman, 2010. Effects of dietary copper exposure on accumulation, growth, and haematological parameters in Cyprinus carpio. Toxicol. Environ. Chem., 92: 1865-1878.

Alkahem-Al-Balawi HF, Z Ahmad, AS Al-Akel, F Al-Misned, EM Suliman and KA Al-Ghanim, 2011. Toxicity bioassay of lead acetate and effects of sub-lethal exposure on growth, haematological parameters and reproduction in Clarias gariepinus. Afr. J. Biotechnol., 10: 11039-11047. 
Anam KK and SK Maitra, 1995. Impact of quinalphos on blood glucose and allied fishes (TV. F. Hund). Fish leaflet Wash, 311: 260.

Banaee M, AR Mirvaghefi, BM Amiri, GR Rafiee and B Nematdost, 2011. Hematological and Histopathological effects of Diazinon Poisoning in common carp (Cyprinus carpio). Ir. J. Nat. Res., 64: 113.

Camargo MM and CB Martinez, 2007. Histopathology of gills, kidney and liver of a Neotropical fish caged in an urban stream. Neotrop. Ichthyol., 5: 327-336.

Detholoff GM, HC Bailey and KJ Maier, 2001. Effect of dissolved copper on selected haematological, biochemical and immunological parameters of wild rainbow trout (Oncorhynchus mykiss). Archi. Environ. Conta. Toxicol., 40: 371-380.

Fernandes MN and AF Mazon, 2003. Environmental pollution and fish gill morphology. In: Val AL, Kapoor BG (Eds.). Fish adaptation Enfield Science Publishers 203-231.

Hossain S, MH Khatun, MK Rahman and M Shahjahan, 2015. Impacts of Sumithion on Blood Glucose and Some Hematological Parameters in Common Carp. Int. J. Environ., 5: 8-13.

Jain NC, 1993. Essentials of Veterinary Hematology, Lea and Febiger, Philadelphia, 417 p.

Jee LH, F Masroor and JC Kang, 2005. Responses of cypermethrin induced stress in haematological parameters of Korean rockfish, Sebastes schlegeli (Hilgendorf). Aqua. Res., 36: 898-905.

Joshi PK, D Harish and M Bose, 2002. Effect of lindane and malathione exposure to certain blood parameters in a fresh water teleost fish Clarias batrachus. Pollution Resources, 21: 55-57.

Lacker R, 1998. Oxidative stress in fish by environmental pollutants. Ecotoxicol., pp. 203-224.

Marti HH, RH Wenger and LA Rivas, 1996. Erythropoietin gene expression in human, monkey and murine brain. European J. Neurosci., 8: 666-676.

Nupur N, M Shahjahan, MS Rahman and MK Fatema, 2013. Abundance of macrozoobenthos in relation to bottom soil textural types and water depth in aquaculture ponds. Int. J. Agril. Res. Innov. \& Tech., 3: 1-6.

Olurin K, E Olojo, G Mbaka and A Akindele, 2006. Histopathological responses of the gill and liver tissues of Clarias gariepinus fingerlings to the herbicide, glyphosate. African J. Biotechnol., 5: 2480-2487.

Parikh PH, A Rangrez, R Adhikari-Bagchi and BN Desai, 2010. Effect of dimethoate on some histoarchitecture of freshwater fish Oreocromis mossambicus (Peters, 1852). The Bioscan, 5: 55-58.

Pckering AD, 1981. Stress and compensation in teleostean fishes: Response to social and physical factors. In: Pickering AD (ed.) Stress and fish. Academic Press, New York, USA, 295-322.

Rahaman MS, M Shahjahan, MM Haque and S Khan, 2012. Control of euglenophyte bloom and fish production enhancement using duckweed and lime. Iranian J. Fish. Sci., 11: 358-371.

Rao DS, 2010. Carbaryl induced changes in the haematological, serum biochemical and immunological responses of common carp, Cyprinus carpio, (L.) with special emphasis on herbal extracts as immunomodulators. Ph. D. Thesis, Andhra University, India. p. 235.

Salam MA, M Shahjahan, S Sharmin, F Haque and MK Rahman, 2015. Effects of sub-lethal doses of an organophosphorous insecticide sumithion on some hematological parameters in common carp, Cyprinus carpio. Pakistan J. Zool., 47: 1487-1491.

Saravana BP and P Geraldine, 2000. Histopathology of the hepatopancreas and gills of the prawn Macrobrachium malcolmsonii exposed to endosulfan. Aquat. Toxicol., 50: 331-339.

Shahjahan M, MF Kabir, KA Sumon, LR Bhowmik and H Rashid, 2016. Toxicity of organophosphorous pesticide sumithion on larval stages of stinging catfish Heteropneustes fossilis. Chinese Journal of Oceanology and Limnology, doi.org/10.1007/s00343-016-5173-3.

Sharker MR, MAB Siddik, A Nahar, M Shahjahan, and AA Faruque, 2015. Genetic differentiation of wild and hatchery populations of Indian major carp Cirrhinus cirrhosus in Bangladesh. J. Environ. Biol., 36: 12231227.

Sharmin S, M Shahjahan, MA Hossain, MA Haque and H Rashid, 2015. Histopathological Changes in Liver and Kidney of Common Carp Exposed to Sub-lethal Doses of Malathion. Pakistan J. Zool., 47: 1495-1498.

Siddika F, M Shahjahan and MS Rahman, 2012. Abundance of plankton population densities in relation to bottom soil textural types in aquaculture ponds. Int. J. Agril. Res. Innov. \& Tech., 2: 56-62.

Talukdar MZH, M Shahjahan and MS Rahman, 2012. Suitability of duckweed (Lemna minor) as feed for fish in polyculture system. Int. J. Agril. Res. Innov. \& Tech., 2: 42-46.

Tomlin CDS, 2006. The Pesticide Manual, A World Compendium, 14th ed.; British Crop Protection Council: Alton, Hampshire, UK, pp. 642-643. 
Uddin MH, M Shahjahan, AKMR Amin, MM Haque, MA Islam and ME Azim, 2016. Impacts of organophosphate pesticide, sumithion on water quality and benthic invertebrates in aquaculture ponds. Aquaculture Reports, 3: 88-92.

Venakataramana GV, PNS Rani and PS Murthy, 2006. Impact of Malathion on the biochemical parameters of gobiid fish, Glossogobius giuris (Ham). J. Environ. Biol., 27: 119-122.

Winkaler EU, TRM Santos, G Joaquim, JG Machado-Neto and CBR Martinez, 2007. Acute lethal and sublethal effects of neem leaf extract on the neotropical freshwater fish Prochilodus lineatus. Comp. Biochem. Physiol. C, 145: 236-244. 